\title{
UPAYA PENINGKATAN KESADARAN MASYARAKAT DESA MATANGAJI TERHADAP PENCEGAHAN COVID-19 MELALUI PEMBUATAN DAN DISTRIBUSI APD
}

\author{
Dein Iftitah ${ }^{1}$, Haryudi $^{2}$ \\ ${ }^{1}$ Universitas Muhammadiyah Cirebon \\ ${ }^{2}$ Universitas Muhammadiyah Cirebon
}

dein.iftitah@umc.ac.id / dein.iftitah@gmail.com, haryudi519@gmail.com

\begin{abstract}
Abstrak
Upaya peningkatan kesadaran masyarakat Desa dalam pencegahan COVID-19 masih sangat perlu dilakukan karena masyarakat Desa masih menganggap virus corona bukan sebagai ancaman, rendahnya kesadaran masyarakat dalam menerapkan protokol kesehatan seperti penggunaan masker dan social distancing serta minimnya alat pelindung diri yang dimiliki masyarakat. Sosialisasi yang dilakukan pemerintah dalam menerapkan aturan pencegahan COVID-19 di masyarakat seperti cuci tangan yang baik, penggunaan masker yang benar dan social distancing (jaga jarak) melalui media sosial masih diabaikan oleh masyarakat sehingga perlu dilakukan penyuluhan dan pelatihan pembuatan serta distribusi APD sebagai penerapan pencegahan COVID-19 di masyarakat Desa. Pengabdian masyarakat ini bertujuan untuk memberikan edukasi tentang bahaya atau ancaman COVID-19 sehingga diharapkan dapat menumbuhkan kesadaran masyarakat Desa dan meningkatkan pemahaman pencegahan COVID-19. Kegiatan Pengabdian kepada Masyarakat dilaksanakan pada tanggal 10 Agustus 2020 - 10 September 2020 di Desa Matangaji Kecamatan Sumber. Metode yang dilakukan adalah Pembuatan dan pendistribusian Alat Pelindung Diri seperti handsanitizer, masker dan melakukan penyemprotan desinfektan serta melakukan sosialisasi pencegahan COVID-19 melalui pemasangan poster dan pendistribusian APD langsung ke Masyarakat Desa. Hasil yang diperoleh adalah pembuatan handsanitizer sebanyak 50 liter telah didistribusikan ke masyarakat Desa Matangaji, sterilisasi melalui penyemprotan telah dilakukan di tempat-tempat umum yang banyak dikunjungi masyarakat Desa Matangaji serta distribusi masker sebanyak 500 masker telah dibagikan kepada masyarakat Desa Matangaji. Setelah dilakukannya sosialisasi melalui pendistribusian APD dan pemasangan poster di beberapa tempat umum seperti Sekolah, Balai Desa dan tempat-tempat yang sering dikunjungi, masyarakat Desa Matangaji memahami tentang cara pencegahan COVID-19 dan masyarakat Desa waspada terhadap bahaya COVID-19 dengan menerapkan protokol kesehatan.
\end{abstract}

Kata Kunci : covid-19, upaya pencegahan, pembuatan dan distribusi apd

\section{PENDAHULUAN}

COVID-19 telah menjadi masalah kesehatan dunia. WHO resmi menyatakannya sebagai suatu pandemi pada 11 Maret 2020.
Pandemi COVID merupakan kondisi darurat global yang terjadi karena infeksi COVID-19 di seluruh dunia. Berdasarkan data WHO tanggal 18 September 2020 jumlah kasus terkonfirmasi positif di seluruh dunia mencapai 30.055 .710 dengan Lingkungan Hidup dan Kebencanaan 
angka kematian 943.433 dapat dilihat pada Gambar 1.

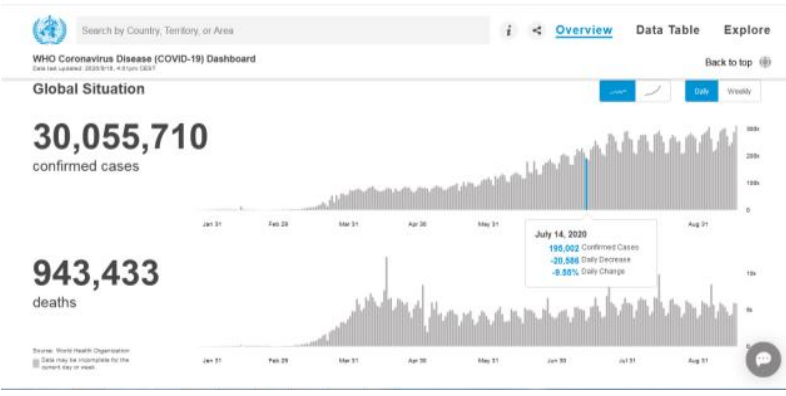

Gambar 1. Data kasus terkonfirmasi positif dan kematian kasus COVID-19 (Sumber : WHO sampai dengan tanggal 18 September 2020).

Kasus terkonfirmasi positif di Indonesia sudah hampir lebih dari 200.000 orang telah terinfeksi oleh COVID-19 (https://srv1.worldometers.info/coronavirus/). Virus corona merupakan jenis virus baru (SARS-CoV-2) dengan nama penyakit yang disebut Coronavirus disease 2019 (COVID-19) (Yuliana, 2020; Parwanto, 2020). Deskripsi fisik coronavirus adalah RNA strain tunggal positif, berkapsul, meliputi demam (suhu> 30oC), batuk, dan kesulitan bernafas. Gejala klinis lain yang ditimbulkan oleh virus ini seperti, sesak nafas, kelelahan, gejala diare dan gejala saluran pernafasan (PDPI, 2020)

Dalam rangka pencegahan penyebaran COVID-19, pemerintah telah melakukan sosialisasi dan himbauan kepada masyarakat untuk menerapkan perilaku hidup bersih dan sehat melalui $3 \mathrm{M}$ yaitu membiasakan diri menggunakan masker, selalu mencuci tangan pakai sabun, dan menjaga jarak. Namun tidak sedikit masyarakat desa yang mengabaikan himbauan tersebut. Masyarakat Desa umumnya banyak yang menganggap bahwa virus corona bukan sebagai ancaman, rendahnya kesadaran masyarakat dalam menerapkan protokol kesehatan seperti penggunaan masker dan social distancing serta minimnya alat pelindung diri yang dimiliki masyarakat.

Sosialisasi yang dilakukan pemerintah dalam menerapkan aturan pencegahan COVID-19 di masyarakat desa masih sering diabaikan sehingga masih perlu dilakukan pengabdian kepada masyarakat dengan memberikan edukasi dan sosialisasi kepada masyarakat desa terutama di Desa Matangaji serta pelatihan pembuatan APD. Salah satu upaya untuk melakukan perlindungan diri terhadap penularan COVID-19 adalah dengan menggunakan alat pelindung diri seperti masker. Selain itu, untuk mengurangi penularan COVID-19 juga dapat menggunakan hand sanitizer dan desinfektan. Handsanitizer merupakan cairan pembersih tangan sebagai alternatif untuk cuci tangan selain menggunakan sabun dan air, sedangkan desinfektan merupakan cairan pembersih yang umumnya dibuat dari hidrogen peroksida, creosote, atau alkohol untuk membunuh bakteri, virus, kuman, protozoa, dan mikroorganisme berbahaya lainnya pada permukaan benda mati atau ruangan (Putri, D, 2020). Pengabdian masyarakat ini bertujuan untuk memberikan edukasi tentang bahaya COVID-19 dan mendistribusikan APD serta melakukan penyemprotan desinfektan pada tempat-tempat umum sebagai upaya pencegahan COVID-19 sehingga dapat meningkatkan kesadaran dan memberikan pemahaman kepada masyarakat desa akan bahaya COVID-19.

\section{METODE}

Kegiatan pengabdian kepada masyarakat dilaksanakan selama 1 bulan mulai 10 Agustus 2020 - 10 September 2020 di Desa Matangaji Kecamatan Sumber Kabupaten Cirebon. Metode pendekatan dalam melakukan pengabdian kepada masyarakat untuk menyelesaikan permasalahan diantaranya melalui pembuatan dan penyemprotan desinfektan, pembuatan dan pendistribusian handsanitizer, pendistribusian masker, pemasangan poster dan banner sebagai upaya edukasi dan sosialisasi pencegahan COVID-19 kepada masyarakat desa.

Pembuatan desinfektan dilakukan dengan referensi yang telah dibuat oleh Haribowo 2020, dengan bahan pembersih lantai yang mengandung Pine oil sebanyak 2,5\%, Ethoxylated alcohol 3\%, Benzalkonium chloride 1,25\%, Natrium Lauril Eter Sulfat 2,5\%. Alcohol Ethoxylate Natrium Lauril Eter Sulfat, Larutan tersebut dimasukan kedalam wadah didalam alat penyemprotan desinfektan. Penyemprotan dilakukan di tempat-tempat umum seperti sekolah, Balai Desa, Masjid dll.

Lingkungan Hidup dan Kebencanaan 
Pembuatan dan pendistribusian hand sanitizer ke tempat-tempat umum seperti balai desa, masjid, dan tempat umum lainnya sebagai alternatif untuk membersihkan tangan tanpa menggunakan air dan sabun. Hand sanitizer dibuat dengan komposisi sesuai dengan standar WHO yaitu dengan kandungan 70\% Ethyl Alcohol, Gliserin, Distiled Water, $\mathrm{H}_{2} \mathrm{O}_{2}$ ) dari bahan-bahan berikut : ethanol 96\%: 8,333 ml. Hidrogen Peroksida 3\%: $417 \mathrm{ml}$. Gliserin 98\%: $145 \mathrm{ml}$ dan 1 liter air suling steril (distiled water). Hand sanitizer dimasukkan kedalam botol dengan diberi label/stiker tim Matangaji Village berukuran $500 \mathrm{ml}$ sebanyak 50 liter.

Pendistribusian masker dengan tujuan agar masyarakat desa mampu melindungi diri dari virus. Masker distribusikan sebanyak 500 Pcs untuk masyarakat desa.

Upaya yang dilakukan untuk sosialisasi tentang pencegahan COVID-19 dengan pembuatan poster dan banner yang dipasang di tempat umum seperti Balai Desa, Masjid, Sekolah dan jalan-jalan utama. Pembuatan poster dan banner menggunakan software atau aplikasi Corel draw versi X7 dengan ukuran banner $3 \times 1 \mathrm{~m}$ dan poster berukuran $29 \times 42$ $\mathrm{cm}$.

\section{HASIL DAN PEMBAHASAN}

\section{Penyemprotan Desinfektan}

Salah satu upaya pencegahan penularan dan penyebaran COVID-19 yaitu dengan menjaga kebersihan diri dan lingkungan. Membersihkan diri dan lingkungan dapat dilakukan dengan menggunakan antiseptik dan desinfektan. Antiseptik merupakan zat yang dapat menghambat pertumbuhan mikroorganisme misalnya hand sanitizer. Desinfektan yang dibuat dengan kandungan glutaraldehid dan formaldehid. Masyarakat desa masih banyak beranggapan bahwa penularan COVID-19 masih bisa dihindari dengan menjauhkan diri dari penderita saja, padahal penyakit ini dapat menyebar melalui partikel-partikel yang menempel pada barangbarang disekitarnya. Misalnya seseorang yang terkonfirmasi positif covid bersin dan tidak ditutup baik dengan tisu atau pun ditutup dengan lengan bagian dalam dapat menularkan ke orang-orang disekitarnya apabila orang yang terjangkit tersebut memegang suatu benda yang ada ditempat umum kemudian orang lain memegang nya dapat menimbulkan adanya transmisi penyakit. (Jin Y-H et al., 2020). Transmisi virus dapat melalui kontak tangan, lingkungan yang terkena virus seperti gagang pintu, meja dan kursi Penyemprotan Desinfektan dilakukan untuk mencegah penyebaran virus corona. Pelaksanaan penyemprotan desinfektan telah dilakukan di Masjid, Kantor Desa dan Sekolah-sekolah atau tempat umum lainnya.

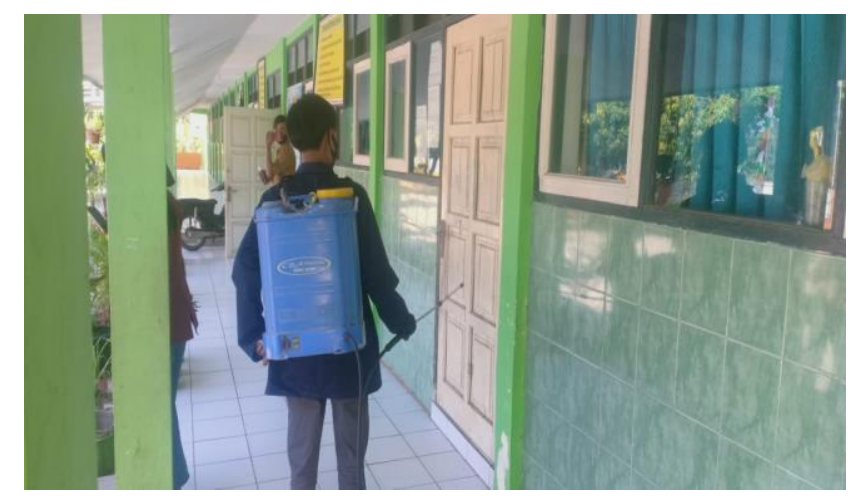

Gambar 2. Penyemprotan desinfektan (Sumber : Dokumentasi pribadi)

Kegiatan penyemprotan desinfektan yang dilakukan di Desa Matangaji dapat dilihat pada Gambar 2. Penyemprotan dilakukan di titik yang diduga sering dilalui seperti gerbang sekolah, gagang pintu, meja, kursi hingga halaman sekolah. Hal ini mengingat kondisi di sekolah mulai melaksanakan kegiatan belajar mengajar dengan kelas terbatas sehingga masih perlu dilakukan pencegahan penyebaran virus Covid-19. Penyemprotan dilakukan sesuai dengan tujuan (Churaez, et all. 2020) untuk mengurangi ataupun menghilangkan jika daerah tersebut sudah terpapar virus corona.

Lingkungan Hidup dan Kebencanaan 602 


\section{Pembuatan dan Pendistribusian Hand sanitizer}

Penggunaan antiseptik bertujuan untuk menghambat pertumbuhan mikroorganisme misalnya yang sering digunakan apabila berpergian atau ada di tempat umum selalu tersedia hand sanitizer. Pembagian / pendistribusian hand sanitizer kepada masyarakat desa dengan tujuan agar masyarakat terbiasa menggunakan hand sanitizer ketika berada di tempat umum seperti Masjid, Kantor desa, Sekolah-sekolah dan tempat umum lainnya. penggunaan hand sanitizer diharapkan mampu meminimalisasi jumlah mikroba yang ada di tangan, meskipun efektifitasnya lebih rendah dibandingkan sabun (Ginting, et all, 2020). Adapun tempat umum yang di berikan handsanitizer meliputi Sekolah-sekolah, Kantor Kuwu Matangaji, Masjid atau tempat ibadah lain dan tempat umum lainnya. Hand sanitizer yang dibuat pada pelaksanaan pengabdian masyarakat ini dengan kandungan $70 \%$ ethyl alkohol, gliserin, Distiled Water dan Hidrogen peroksida. Sebanyak 50 liter dibagikan kepada warga masyarakat desa secara langsung. Hasil pembuatan dan distribusi hand sanitizer yang diberikan kepada warga masyarakat dapat dilihat pada Gambar 3 dan 4.

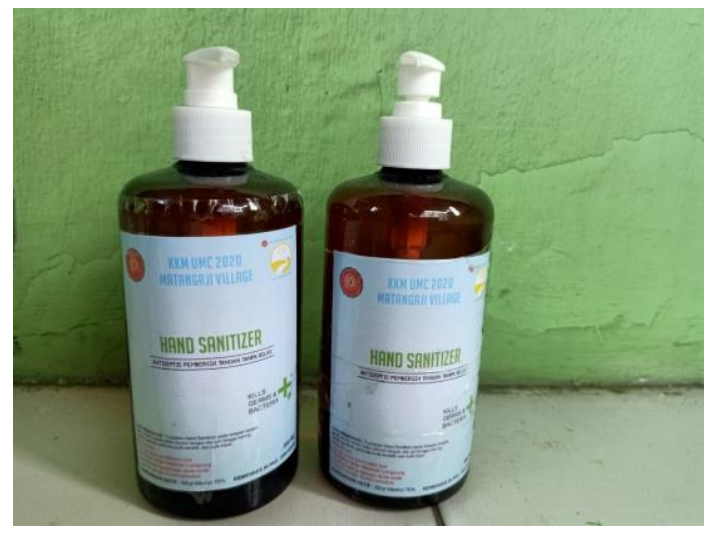

Gambar 3. Handsanitizer

(Sumber : Dokumentasi pribadi)

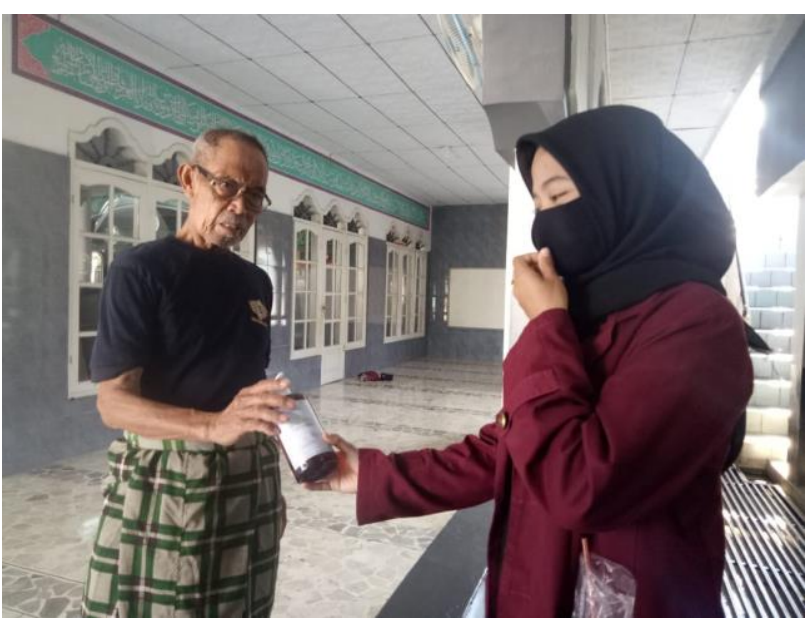

Gambar 4. Distribusi hand sanitizer kepada warga masyarakat Desa Matangaji

Kegiatan pendistribusian handsanitizer dilakukan sebagai bentuk kepedulian kepada masyarakat desa matangaji yang diperkirakan banyak orang yang melakukan kegiatan ditempat tersebut. Pemberian handsanitizer ini diletakan di beberapa titik seperti sekolahsekolah, tempat ibadah seperti masjid, mushola, desa hingga tempat umum dan lain lain. Hal ini mengingat kondisi masyarakat yang sudah mulai melaksanakan kegiatan-kegiatan ditempat umum sehingga masih perlu dilakukan gerakan peduli lingkungan sehat dengan pembagian hand sanitizer dan penyempritan desinfekstan untuk upaya pencegahan Covid19.

\section{Pendistribusian Masker}

Pelaksanaan pembagian / pendistribusian, masker pada kegiatan pengabdian masyarakat ini dilaksanakan bertujuan agar masyarakat terbiasa menggunakan masker ketika beraktivitas di luar rumah. Pembagian masker juga untuk mendukung program pemerintah yang mewajibkan semua lapisan masyarakat untuk memakai masker saat di luar rumah sebagai bagian dari protokol kesehatan di masa pandemi virus Covid 19 (Lestari, et all. 2020).

Lingkungan Hidup dan Kebencanaan

603 


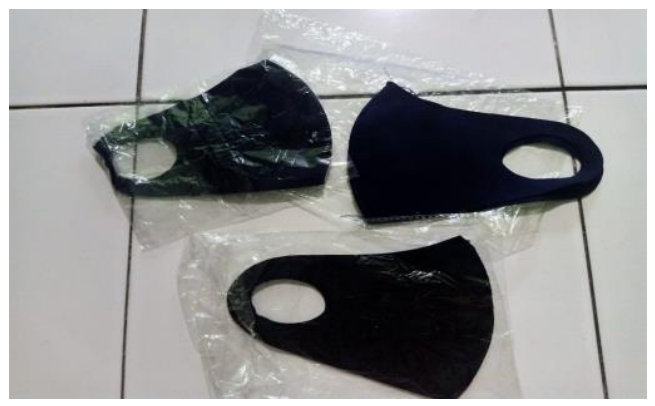

Gambar 5 Masker

(Sumber : Dokumentasi Pribadi)

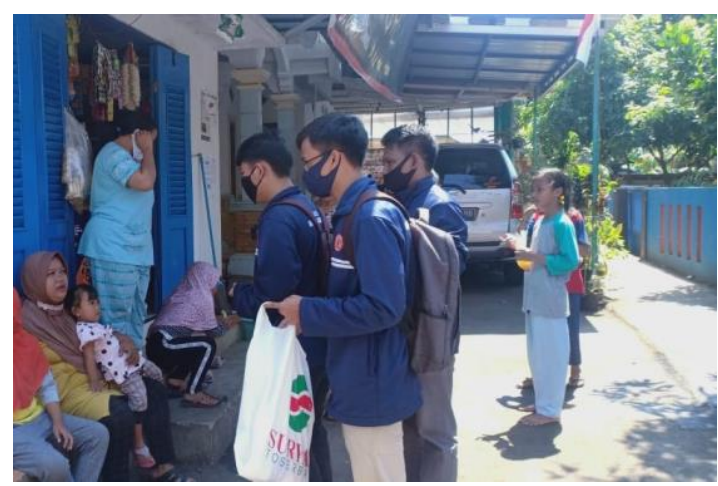

Gambar 6 Pendistribusian Masker

Sumber : Dokumentasi pribadi

Kegiatan pendistribusian masker dilakukan sebagai bentuk keperdulian kepada masyarakat desa matangaji dengan memberikan masker kepada seluruh warga desa matangaji dengan mendatangi rumah-rumah warga. Hal ini mengingat kondisi masyarakat yang sudah mulai melakukan AKB. Maka dari itu pemberian masker ke rumah-rumah warga dilakukan agar dapat mencegah penyebaran covid-19

\section{Pemasangan Poster Dan Banner Sebagai Sarana Sosialisasi Pencegahan COVID-19.}

pelaksanaan pemasangan poster dan banner, tahap ini dilaksanakan bertujuan agar masyarakat mengetahui informasi tentang pencegahan covid-19. Poster tentang pencegahan Covid-19 ini digunakan sebagai edukasi dengan membagikannya dengan cara menempelkan pada lokasi-lokasi strategis dan mudah terbaca. Informasi dan edukasi harus terus menerus disampaikan kepada masyarakat, serta pengawasan juga harus dilakukan agar masyarakat mau menerapkan perilaku sehat (Listina et al., 2020).
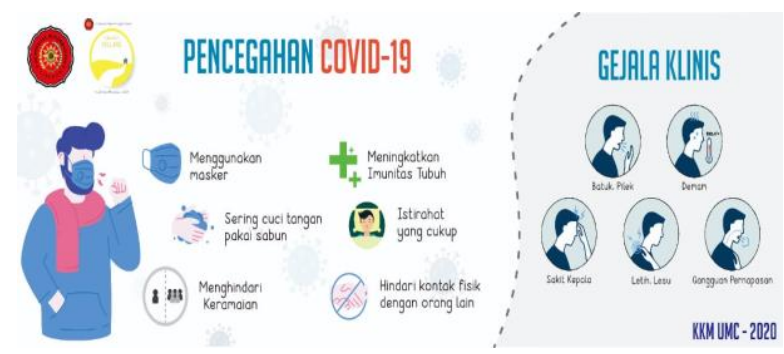

Gambar 7. Banner Sosialisasi Covid-19 (Sumber :Dokumentasi Pribadi)

Kegiatan pemasangan poster dan banner dilakukan sebagai bentuk keperdulian kepada masyarakat di beberapa titik didesa matangaji yang diperkirakan banyak orang yang melakukan kegiatan ditempat tersebut. Pemasangan poster dan banner di pasang di beberapa titik seperti sekolah , masjid, mushola , desa hingga tempat umum dan lain lain. Hal ini mengingat kondisi masyarakat yang sudah mulai melaksanakan kegiatan-kegiatan ditempat umum sehingga dilakukan antisipasi mengingat virus Covid-19 ini sangat bersiko. Maka dari itu pemasangan spanduk dan banner ditempat-tempat uumum dilakukan agar dapat mencegah penyebaran Covid-19.

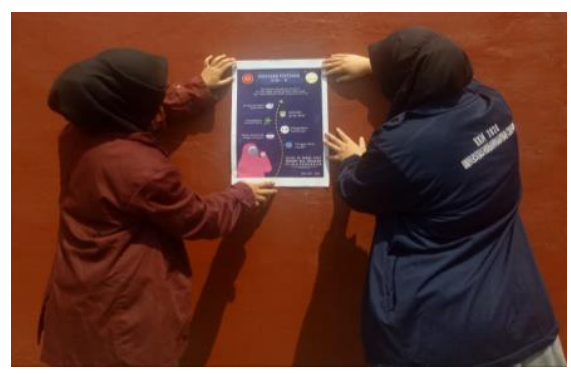

Gambar 10. Pemasangan Poster Lingkungan Hidup dan Kebencanaan 


\section{KESIMPULAN}

Kesimpulan yang diperoleh dari hasil kegiatan pengabdian masyarakat ini yaitu penyemprotan desinfektan dan distribusi antiseptik beripa masker dilaksanakan di tempat-tempat umum seperti sekolah, masjid, musholah, kantor Desa dan lain-lain Pembagian masker kepada masyarakat desa matangaji secara langsung dan lancar dengan sistem dan pemasangan poster dan banner di pasang di beberapa titik seperti sekolah , masjid, mushola , desa hingga tempat umum dan lain lain.

Berdasarkan hasil dan pembahasan yang sudah disampaikan pada pelaksanaan pengabdian masyarakat dalam Upaya Peningkatan Kesadaran Masyarakat di desa Matangaji terhadap Pencegahan COVID-19 melalui Pembuatan dan Distribusi APD. Diperoleh bahwa masyarakat desa Matangaji kecamatan sumber kabupaten cirebon sudah mulai membiasakan diri untuk menggunakan masker, dan meningkatnya pengetahuan tentang pencegahan COVID-19.

\section{REFERENSI}

Astuty, E. (2020). Sosialisasi Pencegahan Covid-19 Di Desa Waiheru Kota Ambon.Jurnal Pengbdian Kepada Masyarakat. 2(1).

Churaez, Fiza Ishlahiyya. Ramdani, Rifngan. Firmansyah, Rizky. Mahmudah, Siti Nur. Ramli, S. W. (2020). Pembuatan dan Penyemprotan Disinfektan: Kegiatan Kkn Edisi. Jurnal Universitas Negeri Malang, 2, 50-55.

http://journal.ummat.ac.id/index.php/JSPU/artic le/download/2485/1680.

Haribowo, C. (2020). Penggunaan Desinfektan dan Antiseptik pada Pencegahan Penularan Covid-19 di Masyarakat. 5(3), 137145.
Herlan, Efriani, Sikwan, A., Hasanah, Bayuardi, G., Listiani, E. I., \& Yulianti. (2020). Keterlibatan Akademisi dalam Menanggulangi Dampak Covid-19 Terhadap Masyarakat Melalui Aksi Berbagi Sembako. JCES (Journal of Character Education Society), 3(2), 267277.

JinY-H,CaiL,ChengZ-

S,ChengH,DengT,FanYP, etal.Arapidadvicegui delineforthediagnosisandtreatmentof2019novel coronavirus $(2019 \mathrm{nCoV})$ infected pneumonia(standardversion).MilitaryMedicalR esearch.2020;7(1):4

Lestari, Putu Asri. Hanindhaputri, Made Arini. Lestari, N. P. E. B. (2020). Gerakan 1.000 masker untuk pencegahan virus covid 19 di pasar yadnya desa adat kesiman denpasar timur. Jurnal Lentera Widya, 1(2), 39-44.

Listina, O., Ika, D., Solikhati, K., \& Fatmah, I. S. (2020). Edukasi corona virus desease 19 ( covid-19 ) melalui penyebaran poster kepada masyarakat kecamatan. 1(2).

Medical Guideline [Diakses September 2020]. Tesedia online :

https://medicalguidelines.msf.org/viewport/Ess Dr/english/antiseptics-anddisinfectants16688206.html

Putri, D, A. (2020). Cara Membuat Desinfektan Alami untuk Mencegah Virus. Dokter Sehat. https://doktersehat.com/caramembuat-desinfektan/

Putri, R. N. (2020). Indonesia dalam Menghadapi Pandemi Covid-19. Jurnal Ilmiah Universitas Batanghari Jambi, 20(2), 705. https://doi.org/10.33087/jiubj.v20i2.1010

Rosalina Ginting, Maftukin Huda, Valdyan Drifanda, A. R. A. (2020). Pemberdayaan Masyarakat Desa Jungsemi di Masa Pandemi Covid 19 Melalui Pelatihan Pembuatan Hand Sanitizer dan Pelindung Wajah | Ginting | IJECS: Indonesian Journal of Empowerment and Community Services.

Lingkungan Hidup dan Kebencanaan $\quad 605$ 
IJECS: Indonesian Journal of Empowerment and Community Services, 1(1), 20. http://journal.univetbantara.ac.id/index.php/ijec s/article/view/780

Sari, M.K. (2020). Sosialisasi tentang Pencegahan Covid-19 di Kalangan Siswa Sekolah Dasar di SD Minggiran 2 Kecamatan Papar Kabupaten Kediri. Jurnal Karya Abdi. 4(1).

Utami, Sri. Permata Dewi, N, A. (2020).
Perancangan Masker Kain Sebagai Alat Pelindung Diri Dalam Sistem Sustainble Fashion. Sekolah Tinggi Desain Bali. https://doi.org/10.35886/damoda.v1i2.81

Yuliana. (2019). Wellness and healthy magazine. Wellness and Healthy Magazine, 2(February), 187-192. https://wellness.journalpress.id/wellness/article/ view/v1i218wh 